\title{
A METHOD FOR THE DETERMINATION OF TWO ALTERNARIA TOXINS, ALTERNARIOL AND ALTERNARIOL MONOMETHYL ETHER, IN TOMATO PRODUCTS
}

\author{
Silvana da Motta; Lucia M. Valente Soares* \\ Faculdade de Engenharia de Alimentos, Universidade Estadual de Campinas, Campinas, SP, Brasil \\ Submitted: June 30, 1999; Returned to authors for corrections: February, 03, 2000; Approved: November 06, 2000
}

\begin{abstract}
Tomatoes, as any soft skinned fruit, are easily susceptible to fungal rot. Alternaria is the genus most frequently encountered in tomatoes. A. alternata and other spp. have been shown to produce the toxins alternariol monomethyl ether (AME) and alternariol $(\mathrm{AOH})$ in tomatoes. A method for determining AME and $\mathrm{AOH}$ in tomato products was developed and evaluated. The method involves extraction with methanol, clarification with ammonium sulfate, and partition to chloroform. Quantification was conducted by high performance liquid chromatography with diode array detector (DAD). Average recoveries were $98.7 \%$ and $84.1 \%$ for $\mathrm{AME}$ and $\mathrm{AOH}$, respectively. The quantification limits of the method, defined as the minimum amount that allowed quantification and confirmation by the DAD detector, were $2.0 \mathrm{ng} / \mathrm{g}$ for AME and $5.0 \mathrm{ng} /$ $\mathrm{g}$ for $\mathrm{AOH}$.
\end{abstract}

Key words: Alternaria, mycotoxins, alternariol monomethyl ether, alternariol, tomatoes

\section{INTRODUCTION}

The genus Alternaria contains many plant pathogens (31). It colonizes a wide number of agriculturally important plants. It can invade healthy as well as weakened or dead plant material before harvest and under certain conditions it will damage stored products (12). The genus produces 71 known mycotoxins and phytotoxins (15). Among the mycotoxins, alternariol (AOH) and alternariol monomethyl ether (AME) (Fig. 1) are reported to be toxins produced in large amounts by toxigenic Alternaria spp. $(5,19,20)$. Among the known fungal sources for these toxins are A. alternata, A. dauci, A. cucumerina, A. solani and $A$. tenuissima (15).

Both toxins cause weakly acute toxic effects as it is shown by their $\mathrm{LD}_{50}$ which is higher than $400 \mathrm{mg} / \mathrm{kg}$ of b.w. for mice. AME is citotoxic and $\mathrm{AOH}$ and AME show sinergistic effects. $\mathrm{AOH}$ is lethal to unborn mice at levels of $100 \mathrm{mg} / \mathrm{kg}$ b.w. (19). Studies have indicated AME to be carcinogenic and a week mutagen by the AMES test utilizing Salmonella typhimurium (14). It acted as a strong mutagen in tests with Escherichia coli (2). No mutagenicity was observed for $\mathrm{AOH}(22)$.
The toxins AME and $\mathrm{AOH}$ have been found in sorghum (3), sunflower seeds (4), barley, wheat, oats (6), olives, tomatoes, mandarin oranges, peppers and melons (13) and pecans (21). Alternaria strains inoculated on apples, tomatoes, blueberries, oranges and lemons produced the toxins $(24,25,29)$ demonstrating the potential for contamination.

Alternaria presents a special problem for tomatoes as it is their most frequent invader (8). This opens the possibility of the presence of mycotoxins in tomato products and their evaluation becomes advisable in order to assess if there exists a risk for consumers. No such data exists on Brazilian products. In order to accomplish that goal a search was conducted in the literature for a suitable analytical method for $\mathrm{AME}$ and $\mathrm{AOH}$ in tomato products.

The use of chloroform (23), acidified chloroform/ethanol (4:1) (17) and methanol/hexane (15:7) (13) has been described for the extraction of AME and $\mathrm{AOH}$ from tomatoes. The cleanup of the extract by partition $(13,17)$ or open silica column $(17)$ has been described and the final separation and quantification of the toxins from tomatoes and other foods has employed thin

\footnotetext{
* Corresponding author. Mailing address: Faculdade de Engenharia de Alimentos, Departamento de Ciências de Alimentos, Caixa Postal 6121, CEP 13081-970, Campinas, SP, Brasil. E-mail: valente@fea.unicamp.br
} 
<smiles>Cc1cc(O)cc2oc(=O)c3c(O)cc(O)cc3c12</smiles>

ALTERNARIOL<smiles>COc1cc(O)c2c(=O)oc3cc(O)cc(C)c3c2c1</smiles>

ALTERNARIOL MONOMETHYL ETHER

Figure 1. Structures of alternariol and alternariol monomethyl ether.

layer chromatography $(6,7,29)$ or high performance liquid chromatography with detection by absorbance in the ultraviolet, by fluorescence or by electrochemistry $(6,18,23,29)$. Surprisingly, the diode array detector (DAD) has been little used for mycotoxins $(26,27,28)$ and has not been used for AME and $\mathrm{AOH}$. Yet it can be an useful tool for mycotoxins determinations (16). The DAD detector, besides working as the usual UV detector in the quantification process, can also provide the analyst with the UV spectra of the compound of interest and of the standard employed. If the compound of interest elutes without interferences, the analyst may be able to confirm the identity of the toxin by comparing the spectra of the suspected peak and of the standard. This will free the analyst from having to use other techniques for confirmation of the identity of the analyte. Such techniques may involve chemical reactions, mass spectrometry, infrared or ultraviolet spectrometry or immunoaffinity methods and may be tedious and expensive or, in the case of mass spectrometry, simply not available at the institution where the work is being performed.

The present paper describes a method for the determination of $\mathrm{AME}$ and $\mathrm{AOH}$ in tomato products. The extraction and cleanup steps are simple to perform and use easily available solvents and reagents. High performance liquid chromatography and diode array detection (DAD) were used for quantification and confirmation of identity. The intralaboratory evaluation of the method performance is also described.

\section{MATERIALS AND METHODS}

\section{Reagents}

Analytical grade methanol, chloroform, anhydrous sodium sulfate, and hepta hydrate zinc sulfate and HPLC grade methanol were obtained from Merck (Darmstadt, Germany). The alternariol and alternariol monomethyl ether standards were purchased from Sigma (St. Louis, MO, USA). Solutions containing $0.133 \mathrm{mg} / \mathrm{ml} \mathrm{AME}$ and $0.500 \mathrm{mg} / \mathrm{ml} \mathrm{AOH}$ were prepared in methanol. Working standards were then prepared by dilution according with the need. Standard solutions were sonicated before use.

\section{Sample preparation}

Tomato products such as tomato juice, pulp, paste, purée, and whole stewed tomatoes were blended or shaken for homogeneity. A $50 \mathrm{~g}$ portion of the product was weighed and transferred to blender cup with the help of $150 \mathrm{ml}$ methanol. It was blended at low speed for 3 minutes and transferred to a glass funnel fitted with a fluted filter paper. An additional $50 \mathrm{ml}$ methanol was used for washing the residues left in the blender cup into the filter paper. An aliquot of $200 \mathrm{ml}$ of the filtrate was collected into a beaker and $60 \mathrm{ml}$ of a $10 \%$ ammonium sulfate solution was added. The mixture was filtered through fluted filter paper. An aliquot of $200 \mathrm{ml}$ of the filtrate, or less, was then transferred to a separating funnel and $50 \mathrm{ml}$ of water at $8^{\circ} \mathrm{C}$ or below were added. Two extractions with $40 \mathrm{ml}$ chloroform, shaking for 2 minutes each time, were conducted. All the chloroform was collected in a separating funnel and washed with $30 \mathrm{ml}$ ultra pure water at $5-8^{\circ} \mathrm{C}$. The chloroform was then transferred to a graduated cylinder and the volume noted for future calculations. The chloroform extract was evaporated in a rotary evaporator at $35^{\circ} \mathrm{C}$. The residue was dissolved in $2 \mathrm{ml}$ methanol and filtered through anhydrous sodium sulfate.

\section{Liquid chromatography}

The HPLC system consisted of a Hewlett-Packard HP 1050 liquid chromatograph (Hewlett-Packard, Palo Alto, CA, USA) equipped with a Rheodyne sample valve fitted with a $20 \mathrm{ml}$ loop and an HP diode array detector (model 1050, Phoenix and Macro Spectro softwares). The analytical column was Spherisorb ODS-2, $5 \mathrm{~mm}, 250 \mathrm{~mm}$ (Phase Separations, Deeside, Chwyd, UK). The sample and standards solutions were sonicated for 30 seconds before injection into the chromatograph. The mobile phase was methanol/water (80:20) 
containing $300 \mathrm{mg} \mathrm{ZnSO}{ }_{4} . \mathrm{H}_{2} \mathrm{O} / \mathrm{L}, 0.7 \mathrm{ml} / \mathrm{min}$. The wavelength for recording chromatograms was $250 \mathrm{~nm}$. A calibration curve was constructed for quantification purposes using the toxin standards and correlating peak-area versus concentration. The peak identity was confirmed by means of comparing the spectrum of the standard with the presumptive positive peak in the sample after normalization. Quantification limits of the method were taken as the minimum amount of the toxin detected in the product that allowed for confirmation by the multiple wavelength detector. The detection limits of the pure toxins by the DAD detector were measured as three times the baseline standard variation under the same conditions employed for the tomato products.

\section{RESULTS AND DISCUSSION}

Several techniques for extraction and cleanup of AME and $\mathrm{AOH}$ described in the literature were tried, either isolated or in combination, with unsatisfactory results in terms of recovery, time involved in performing the analysis, or use of large quantities of solvents, some highly toxic. All this led to the development of the method described in the present paper.

The intralaboratorial evaluation of the proposed method involved the following tests: recovery, precision, and limit of detection and ruggedness. The average recoveries for seven levels of addition of pure standards to tomato paste were $98.7 \%$ and $84.1 \%$ for $\mathrm{AME}$ and $\mathrm{AOH}$, respectively. Recoveries of $70 \%$ and above are considered acceptable for trace analyses at ung/g levels (11). The average RSDs between duplicates for 14 sample preparations, for spiked tomato product samples
(Fig. 2), were $0.8 \%$ for $\mathrm{AME}$ and $5.4 \%$ for $\mathrm{AOH}$, indicating an excellent precision for proposed method. Horwitz et al. $(10,11)$ demonstrated that at levels of $1 \mathrm{ng} / \mathrm{g}$ interlaboratory precision of well conducted tests with blind samples can reach $45 \%$. Duplicates of the same sample analyzed in the same laboratory can be within $2 / 3$ or $1 / 2$ of this value. These apparently high RSD values are a consequence of the difficulties involved in quantifying substances at trace levels. Horwitz (9) also showed that at the $20 \mathrm{ng} / \mathrm{g}$ level most interlaboratory results for the same sample have RSD values of $30 \%$ and within-laboratory RSDs of $20 \%$.

The detection limits of the DAD detector for pure standards were taken as three times the baseline standard deviation according to the guidelines of the American Chemical Society Subcommittee on Environmental Analytical Chemistry (1). The wavelength was set at $250 \mathrm{~nm}$. The detection limits were $0.6 \mathrm{ng}$ and $1.0 \mathrm{ng}$ for $\mathrm{AME}$ and $\mathrm{AOH}$, respectively. The method quantification limits for the same toxins were taken as the minimum amount of the toxin detected in a tomato product that allowed quantification and confirmation by the DAD detector. They were $2.0 \mathrm{ng} / \mathrm{g}$ and $5.0 \mathrm{ng} / \mathrm{g}$ for AME and $\mathrm{AOH}$, respectively. The calibration curves were linear in the range of use, $0.57-12.04 \mathrm{ng} / \mathrm{ml}$, with a correlation coefficient of 0.9932 , for AME and 0.37-15.0 ng/ml, with a correlation coefficient of 0.9995 , for $\mathrm{AOH}$. The comparison between the spectra of the pure standards and of the toxins added to the tomato matrix (Fig. 3) allows the conclusion that the separation of the toxin was complete and that there was no interfering compounds.

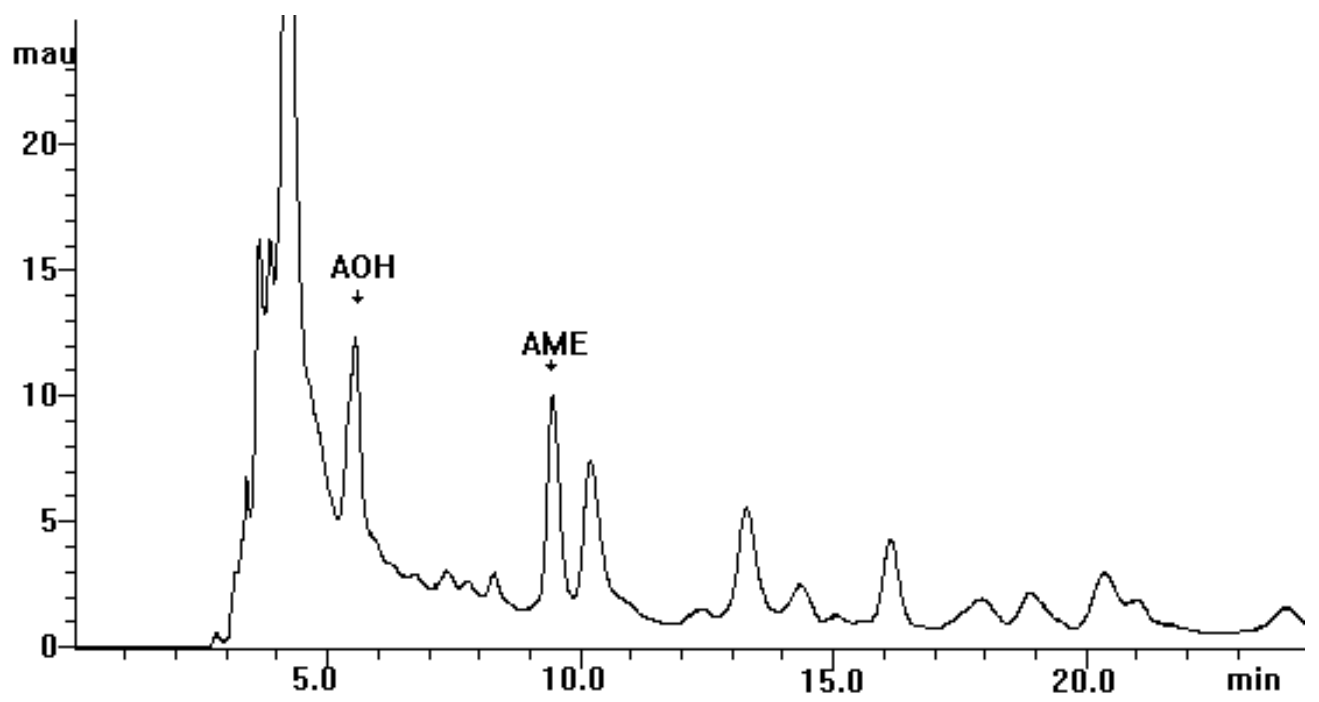

Figure 2. Chromatogram of an uncontaminated tomato paste sample spiked with AME and AOH. Chromatographic conditions: $\mathrm{C} 18$ Spherisorb ODS-2 250x4,6 mm, $5 \mathrm{~mm}$ column, methanol/water $(80+20)$ with $300 \mathrm{mg} \mathrm{ZnSO}{ }_{4} .7 \mathrm{H}_{2} \mathrm{O} / \mathrm{L}, 0.7 \mathrm{ml} / \mathrm{min}$ as mobile phase. DAD detector at $250 \mathrm{~nm}$, response in terms of absorvance units X $10^{-3}$ (mau). Volume injected: $20 \mathrm{ml}$. 

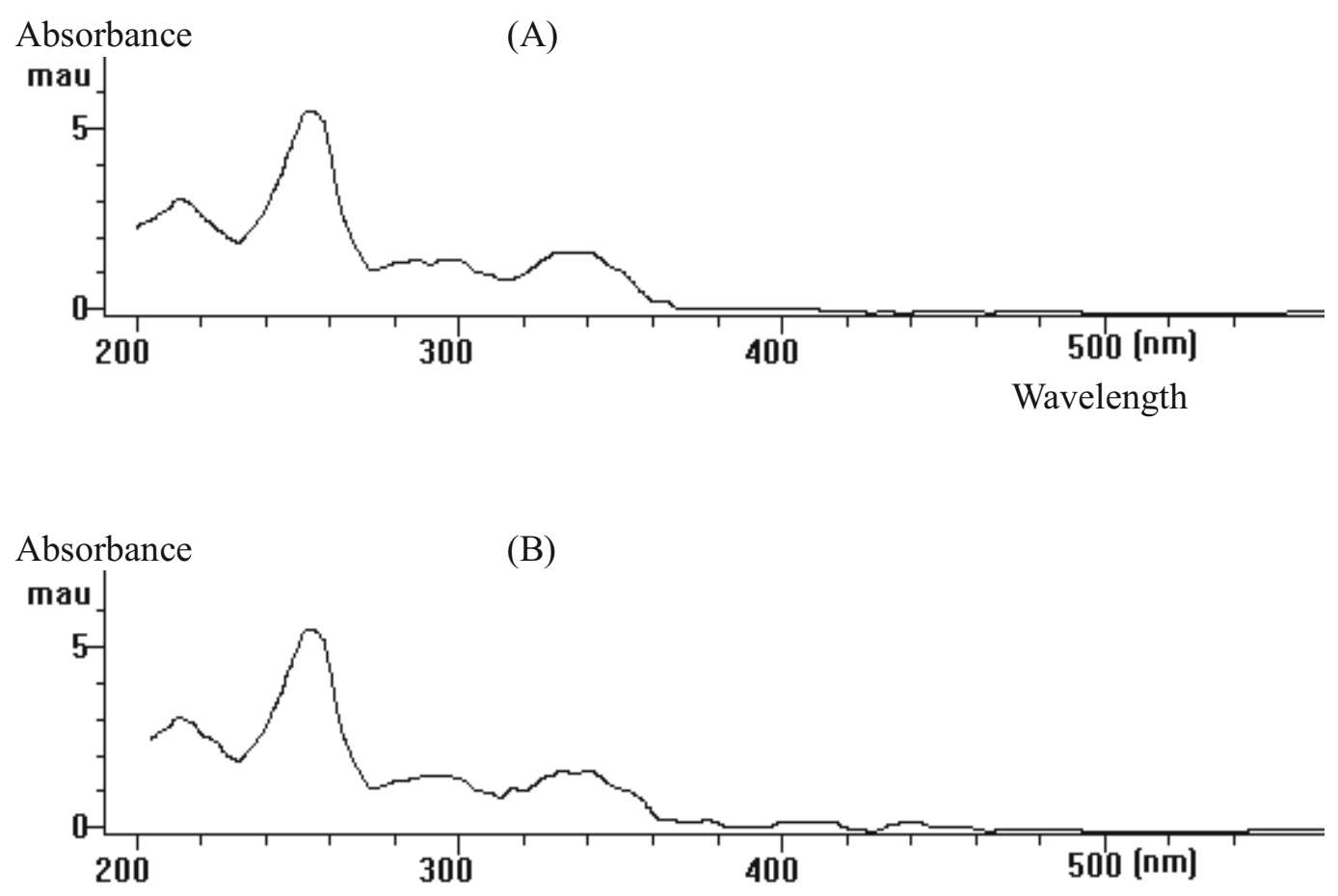

Wavelength
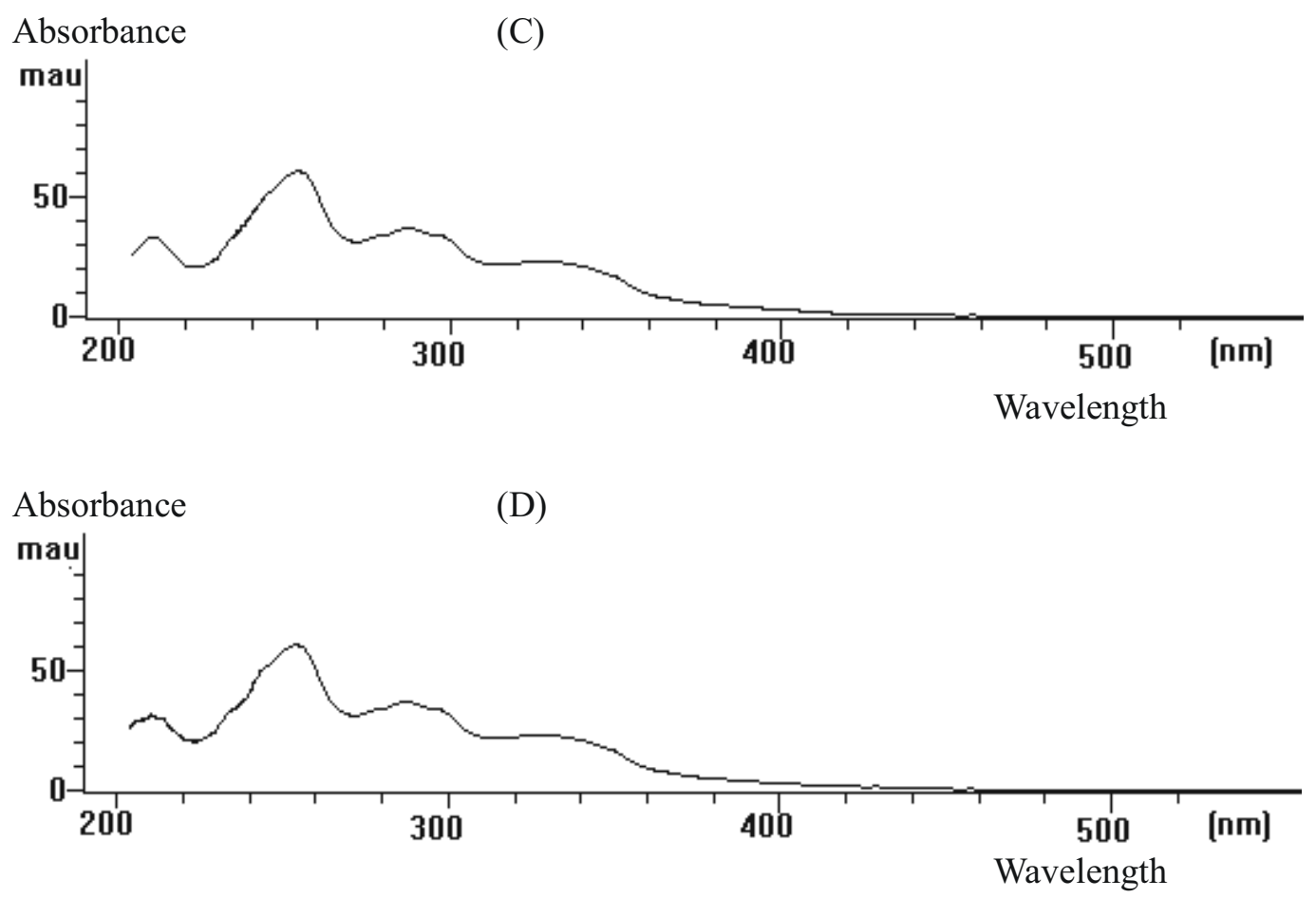

Figure 3. Spectra of AME by a pure standard (A) and in spiked tomato paste (B) and of AOH by a pure standard (C) and in a spiked tomato paste (D) (see chromatogram in Fig. 2). 
A ruggedness test was conducted according to Wernimont (30). It evaluates the behavior of the method in the face of small changes in the working conditions. The conditions evaluated were solvents quality and volumes, concentration of the solution of ammonium sulfate used as clarifying agent, and temperature used for final drying of the extract. The recoveries ranged from 85.9 to $88.6 \%$ and from 76.3 to $92.8 \%$ for $\mathrm{AME}$ and for $\mathrm{AOH}$, respectively. They indicate a good degree of ruggedness in the procedure being tested. The isolated factors show the importance of some of the factors studied in the recoveries of the toxins. It showed also that AME was less affected by changes in the analytical procedure. The quality of the chloroform followed by that of the methanol were the most important variables for the recovery of $\mathrm{AOH}$. Different brands of solvents may contain different amounts and types of impurities. These impurities, usually other organic compounds, change the polarity of the solvent and may affect the recovery of any compound sensitive to small changes in polarity of an extracting or eluting solvent.

\section{ACKNOWLEDGEMENTS}

The authors thank the Fundação de Amparo à Pesquisa do Estado de São Paulo (FAPESP) for the financial support to this work and the Coordenação de Aperfeiçoamento de Pessoal de Nível Superior for the graduate scholarship granted to the first author.

\section{RESUMO}

\section{Um método para determinação de duas toxinas de Alternaria, alternariol monometil éter e alternariol, em produtos de tomate}

Tomates são frutas de pele fina e assim facilmente susceptíveis a deterioração por fungos. Alternaria é o gênero que mais freqüentemente invade tomates. A. alternata e outras espécies deste gênero produzem as toxinas alternariol $(\mathrm{AOH}) \mathrm{e}$ alternariol monometil (AME). Um método analítico para determinação de $\mathrm{AME}$ e $\mathrm{AOH}$ em produtos de tomate foi desenvolvido e avaliado. O método consiste em uma extração com metanol, clarificação com sulfato de amônio e partição para clorofórmio. Quantificação foi executada por cromatografia líquida de alta eficiência com detetor de arranjo de diodos (DAD). Recuperações médias foram 98,7\% e 84,1\% para AME e AOH, respectivamente. Os limites de deteç̧ão do método, definidos como a menor quantidade das toxinas que permitiu quantificação e confirmação pelo DAD, foram 2,0 ng/g para AME e 5,0 ng/ $\mathrm{g}$ para $\mathrm{AOH}$.

Palavras-chave: Alternaria, micotoxinas, alternariol monometil éter, alternariol, tomate

\section{REFERENCES}

1. ACS Committee on Environmental Improvement, Guidelines for data acquisition and data evaluation in environmental chemistry. Anal. Chem., 52:2242-2249, 1980.

2. An, Y.; Zhao, T.; Miao, J.; Liu, G.; Zheng, Y.; Xu, Y.; Van Etten, R.L. Isolation, identification, and mutagenicity of alternariol monomethyl ether. J. Agric. Food Chem., I37:1341-1343, 1989.

3. Ansari, A.A.; Shrivastava, A.K. Natural occurrence of Alternaria toxins in sorghum and ragi from North Bihar, India. Food Add. Contam., 7:815-820, 1990.

4. Chulze, S.N.; Torres, A.M.; Dalcero, A.M.; Etcheverry, M.G.; Ramirez, M.L.; Farnochi, M.C. Alternaria mycotoxins in sunflower seeds: Incidence and distribution of the toxins in oil and meal. J. Food Protec., 58:1133-1135, 1995.

5. Combe, R.G.; Jacobs, J.J.; Watson, T.R. Metabolite of some Alternaria species. The structure of altenuisin and dehydroaltenuisin. Aus. J. Chem., 23:2343-2351, 1970.

6. Gruber-Schley, S.; Thalmann, A. Zum Vorkommen von Alternaria spp. Und derem Toxine in Getreide un mögliche Zusammenhägen mit Leistungsminderungen landwirtschaftlicher Nutziere. Landwirtsch, Forchung, 41:11-29, 1988.

7. Harwig, J.; Scott, P.M.; Stoltz, d.R.; Blanchsfield, B.J. Toxins of molds from decaying tomato fruit. Appl. Environ. Microbiol., 38:267-274, 1979.

8. Hasan, H.A.H. Alternaria toxins in black rot lesion of tomato fruit: conditions and regulation of their production. Mycopathologia, 130:171-177, 1995.

9. Horwitz, W. Effects of scientific advances on the decision-making process: analytical chemistry. Fund. Appl. Tox., 4:5309-5317, 1984.

10. Horwitz, W.; Albert, R.; Nesheim, S. Reliability of mycotoxins assays - An update. J. AOAC Int., 76:461-491, 1993.

11. Horwitz, W.; Kamps, L.R.; Boyer, K.W. Quality assurance in the analysis of foods for trace constituents. J. Assoc. Off. Anal. Chem., 63:1344-1354, 1980.

12. Kwasna, H. Ecology and nomenclature of Alternaria. In: Chelkowski, J.; Visconti, A. (eds). Alternaria: Biology, plant diseases and metabolites. Elsevier, Amsterdam, 1992, p. 63-100.

13. Logrieco, A.; Bottalico, A.; Visconti, A.; Vurro, M. Natural occurrence of Alternaria mycotoxins in some plant products. Microbiologie, Aliments, Nutrition, 6:13-17, 1988.

14. McCann, J.; Choi, J.; Iamasaki, E.; Ames, B.N. Detection of carcinogens as mutagens in the Salmonella/ microsome test: Assay of 300 chemicals. Proc. Nat. Acad. Sci. U.S.A., 72:39-47, 1981.

15. Montemurro, N.; Visconti, A. Alternaria metabolites, chemical and biological data. In: Chelkowski, J.; Visconti, A. (eds). Alternaria: Biology, plant diseases and metabolites. Elsevier, Amsterdam, 1992, p. 449-557.

16. Motta, S.; Valente Soares, L.M. Simultaneous determination of tenuazonic and cyclopiazonic acids in tomato products. Food Chem., In press.

17. Ozcelik, S.; Ozcelik, N.; Beuchat, L.R. Toxin production by Alternaria alternata in tomatoes and apples stored under various conditions and quantitation of the toxins by high-performance liquid chromatography. Int. J. Food Microbiol., 11:187-194, 1990.

18. Palmisano, F.; Zamboni, P.G.; Visconti, A.; Botalico, A. Determination of Alternaria mycotoxins in foodstuffs by gradient elution liquid chromatography with eletrochemical detection. Chromatographia, 27:425-430, 1989.

19. Pero, R.W.; Harvan, D.; Blois, M.C. Isolation of the toxin, altenuisol, from the fungus, Alternaria tenuis Auct. Tetrahedron Lett., 12: 945948, 1973.

20. Rosett, T.; Sankhala, R.H.; Sitckings, C.E.; Taylor, M.E.U.; Thomas, R. Studies in the biochemistry of microorganisms. Metabolites of Alternaria tenuis Auct: culture filtrate products. Biochem. J., 67:390-400, 1957.

21. Schroeder, H.W.; Cole, R.J. Natural occurrence of Alternariols in discolored pecans. J. Agric. Food Chem., 25:204-206, 1977 
21. Scott, P.M.; Stoltz, D.R. Mutagens produced by Alternaria alternata. Mutation Res., 78:33-40, 1980.

22. Stack, M.E.; Mislivec, P.B.; Roach, J.A.; Pohland, A.E. Liquid chromatographic determination of tenuazonic acid and alternariol methyl ether in tomatoes and tomato products. J. Assoc. Off. Anal. Chem., 68:640-642, 1985.

23. Stinson, E.E.; Bills, D.D.; Osmn, S.F.; Siciliano, J.; Ceponis, M.J.; Heisler, E.G. Mycotoxin production by Alternaria species grown on apples, tomatoes, and blueberries. J. Agric. Food Chem., 28: $960-$ $963,1980$.

24. Stinson, E.E.; Osman, S.F.; Heisler, E.G.; Siciliano, J.; Bills, D.D. Mycotoxin production in whole tomatoes, apples, and lemons. $J$. Agric. Food Chem., 29:790-792, 1981.
25. Sydenham, E.W.; Shephard, G.S. In: Gilbert, J. (ed). Progress in food contaminant analysis. Blackie Academic and Professional, London, 1996, p.65-146.

26. Trucksess, M. Mycotoxins. J. AOAC Int., 81:128-137, 1998.

27. Trucksess, M. Mycotoxins. J. AOAC Int., 82:488-495, 1999.

28. Visconti, A.; Logrieco, A.; Bottalico, A. Natural occurrence of Alternaria mycotoxins in olives - their production and possible transfer into the oil. Food Add. Contam., 3:323-330, 1986.

29. Wernimont, G.T. Use of statistics to develop and evaluate analytical methods. AOAC, Arlington, 1985, 183 p.

30. Yu, S.-H. Occurrence of Alternaria species in countries of the far east and their taxonomy. In: Chelkowski, J.; Visconti, A. (eds). Alternaria: Biology, plant diseases and metabolites. Elsevier, Amsterdam, 1992. p. 37-62. 